Sains Malaysiana 49(11)(2020): 2763-2772

http://dx.doi.org/10.17576/jsm-2020-4911-15

\title{
Assessment of Knowledge, Attitude and Practice among House Officers in UKM Medical Centre on Needle Stick Injuries
}

(Penilaian Pengetahuan, Sikap dan Amalan dalam Kalangan Doktor Pelatih di Pusat Perubatan UKM mengenai Kecederaan Batang Jarum)

\author{
Ahmad Syahmi Mohd Azman, Khairulini Mohd Amirol, Lee Pei Chieh, Nurshafiqah Rosli, Nur Anis \\ NADiRAH ZulKifli, KHAMSIAH NAWAWI \& NUR AZlina MOHD FAHAMI*
}

\begin{abstract}
Needle stick injury is one of the most serious occupational hazards among house officers in which it may lead to possible severe consequences such as HIV, Hepatitis B, and C infection. The aim of the study was to explore and compare the knowledge, attitude and practice (KAP) among house officers of UKM Medical Centre (UKMMC) regarding needle stick injury. A cross-sectional study was conducted with the total of 151 self-administered questionnaires from house officers in UKMMC within the period of five months. The data was collected via universal sampling method. Components evaluated were prevalence, demographic data and scores on KAP concerning needle stick injury among house officers. Out of the 151 house officers recruited for the study, 34.9\% of them had a history of needle stick injury during their practice, with $6.7 \%$ of the injury that occurred in their current posting department. There was a significant association $(p<0.05)$ between history of needle stick injury and the practice of house officers $(p=0.035)$. House officers with a history of needle stick injury had a lower mean score of practice (8.65 \pm 2.00$)$ compared to those without history (9.40 \pm 1.09$)$. This study also demonstrated that there were significant correlations between Knowledge-Practice $(r=0.194, p=0.018)$ and Attitude-Practice $(r=0.182, p=0.026)$ of UKMMC house officers. These findings demonstrated that a good level of knowledge and attitude results in better practice of house officers hence reducing the incidence of needle stick injury. Therefore, suitable health education programs with regards to needle stick injury and preventive measures should be intensively implemented on all house officers prior to and during their practice.
\end{abstract}

Keywords: Blood borne pathogens; health personnel; hospital; house officer; needle stick; sharps object

\section{ABSTRAK}

Kecederaan batang jarum adalah salah satu bahaya pekerjaan yang paling serius dalam kalangan doktor pelatih kerana ia boleh mengakibatkan kemungkinan akibat yang teruk seperti jangkitan HIV, Hepatitis B dan C. Tujuan kajian ini adalah untuk mengkaji dan membandingkan pengetahuan, sikap dan amalan (KAP) dalam kalangan doktor pelatih di Pusat Perubatan UKM (UKMMC) mengenai kecederaan batang jarum. Suatu kajian rentas dijalankan dengan jumlah 151 soal selidik yang dikendalikan sendiri oleh doktor pelatih di UKMMC dalam jangka masa lima bulan. Data dikumpulkan melalui kaedah persampelan sejagat. Komponen yang dinilai adalah prevalens, data demografi dan skor KAP mengenai kecederaan batang jarum dalam kalangan doktor pelatih. Daripada 151 doktor pelatih yang direkrut untuk kajian ini, 34.9\% daripadanya mempunyai sejarah kecederaan batang jarum semasa menjalankan tugas, dengan $6.7 \%$ kecederaan berlaku di jabatan mereka bertugas sekarang. Terdapat hubungan yang signifikan $(p<0.05)$ antara sejarah kecederaan batang jarum dan amalan doktor pelatih $(p=0.035)$. Doktor pelatih yang mempunyai sejarah kecederaan batang jarum mempunyai skor min latihan yang lebih rendah ( $8.65 \pm 2.00)$ berbanding dengan yang tidak mempunyai sejarah $(9.40 \pm 1.09)$. Kajian ini juga menunjukkan bahawa terdapat hubungan yang signifikan antara Pengetahuan-Amalan $(r=0.194, p=0.018)$ dan Sikap-Amalan $(r=0.182, p=0.026)$ doktor pelatih UKMMC. Keputusan ini menunjukkan bahawa tahap pengetahuan dan sikap yang baik menghasilkan amalan doktor pelatih yang lebih baik lalu mengurangkan kejadian kecederaan batang jarum. Oleh itu, program pendidikan kesihatan yang sesuai berkaitan dengan kecederaan batang jarum dan langkah pencegahan harus dijalankan secara intensifkepada semua doktor pelatih sebelum dan semasa menjalankan tugas.

Kata kunci: Batang jarum; doktor pelatih; hospital; objek tajam; patogen bawaan darah; pegawai kesihatan 


\section{INTRODUCTION}

Centres for Disease Control and Prevention (CDC) defines a needle sticks injury (NSI) as an accidental skinpenetrating stab wound from a hollow-bore needle (or any sharp object) containing another person's blood or body fluid (CDC 2008). The CDC estimates that about 385,000 sharps- related injuries occur annually among healthcare workers $(\mathrm{HCW})$ in hospitals. It was also reported that $37.6 \%$ of hepatitis B, $39 \%$ of hepatitis C, and $4.4 \%$ of Human Immunodeficiency Virus (HIV)/AIDS among HCWs around the world are due to NSIs (WHO 2002).

Healthcare workers who perform invasive procedures with sharp instruments are at risk of being exposed to different blood-borne pathogens. There are more than 20 blood-borne diseases (Saleem et al. 2010), but those of primary significance to healthcare workers are Hepatitis $\mathrm{B}$ virus (HBV), Hepatitis C virus (HCV) and acquired immunodeficiency virus (HIV) (Bilkis 2005; Rhode et al. 2013; Roger \& Goodno 2000; Sharew et al. 2017).

Each year, hundreds of thousands of healthcare workers are at risk of occupationally acquired bloodborne diseases as a result of NSIs (Calver et al. 1997; Vaz et al. 2010). According to the United States Occupational Safety and Health Administration (US-OSHA), about 5.6 million HCWs in the healthcare industry are at risk of occupational exposure to blood-borne diseases via percutaneous injury (Kirchner 2012). It was indicated that NSIs are responsible for $37.6 \%$ of HCWs contracting $\mathrm{HBV}, 39 \% \mathrm{HCWs}$ contracting $\mathrm{HCV}$, and $4.4 \% \mathrm{HCWs}$ contracting HIV infection (Nagandla et al. 2015).

After a needle-stick injury from a needle contaminated with $\mathrm{HBV}$, there is a $6-30 \%$ chance that an exposed susceptible person will be infected. In a similar situation with HIV, there is a $0.3 \%$ risk of infection. Occupational acquisition of $\mathrm{HCV}$ infection after exposure is approximately $1.8 \%$ (Zhang et al. 2009). These injuries constitute a major threat to HCWs' psychophysical wellbeing. House officers (HO) are more prone to needle stick injuries because of their relative inexperience and lack of knowledge regarding instruments, sharps handling, and its disposal. This was confirmed by a study done in London and Sheffield, which shows that 25 out of 78 house officers who were surveyed admitted to a needle stick injury in the first 6 months of housemanship (Woolley et al. 1991).

Sharp injuries are preventable under the Occupational Safety and Health Act 1994 (OSHA). Comprehensive programs such as sharp injuries surveillance should be implemented to reduce the injuries. However, according to Anuar et al. (2009), the level of knowledge and awareness towards occupational safety and health (OSH) aspects among workers in medical laboratories within Klang Valley was low. Only $60.5 \%$ of the respondents were aware that OSHA 1994 exists.

Given the importance of the issue and the lack of similar studies in Malaysia, hence, the present study was done to assess the knowledge, attitude, practice, and prevalence of NSIs and sharp injuries among housemen in a particular teaching hospital in Kuala Lumpur. The results can be used to plan preventive measures from these injuries. Thus, the aim of the study was to assess the prevalence of NSIs among house officers and to explore the knowledge, attitude and practices of house officers in UKM Medical Centre regarding NSI.

\section{Methods}

A cross sectional survey was conducted in April 2018 among house officers in UKM Medical Center (UKMMC). Universal sampling technique was used in which a total of 151 house officers who gave consent to be a part of the study were informed about the design and purpose of the study. No sample size was calculated due to the universal sampling. The list of UKMMC house officers was obtained from the Occupational, Safety, Health and Environment division of UKMMC with due permission. Subjects were approached through face-to-face contact and were not given any educational materials on topic after answering the questionnaire. The anonymity of the participants was maintained throughout the study.

Data for the main study were collected using a validated questionnaire previously described by Bhargava et al. (2013). A written approval and consensus were obtained prior to the beginning of the study. The questionnaire was re-validated among the population before the survey was conducted. The self-administered questionnaire was structured specifically to identify predictive factors associated with needle stick injuries. It was used to collect the data qualitatively and quantitatively. The questionnaire was divided into the following subscales; baseline data and NSIs knowledge, attitudes, and practice. The questionnaire contains five questions for each subscale. Each correct answer scored two marks and zero marks were given to incorrect answers. Each category had maximum of ten marks.

Zero to four signifies a poor performance; five and six denotes an average performance, seven and above is a satisfactory performance. The knowledge, attitude, and practice scores were calculated for each respondent and grouped based upon their years of experience, and the education background. The groups were then compared.

Data was then entered into IBM SPSS Statistics Version 24. Descriptive data were described using frequencies, percentages, means, standard deviations and medians. T-test was used to determine the association between the mean KAP score and their demographic data (years of experience, gender and education) (Table 5). Spearman Correlation were used for the comparison of the ranked values for each variable. Ethical approval for the study was obtained from UKMMC Medical Research and Ethics Committee. Ethical approval code is FF-2018180. Written permission was obtained from the original developers of the questionnaire. 


\section{RESULTS}

\section{RESPONSE RATE AND SOCIO-DEMOGRAPHIC CHARACTERISTICS}

From a total of 204 house officers who were working at UKMMC within the study period (April-September 2018), 151 of them agreed to participate with the given response rate of $74 \%$. Majority of the respondents were female $(64.9 \%)$. The mean age of respondents was 26.98 years old (SD 1.6, range 24 - 37 years), with the median age of 27. The distribution between current departments was adequate, ranging from $15.9-22.5 \%$. There were more local graduates $(54.3 \%)$ compared to overseas graduates. Majority (72.8) of respondents had 1 year and above working experience. $36.4 \%$ of the total respondents had a history of NSI and $23.2 \%$ of them had at least one total NSI per year whereas the rest were two to four total NSIs per year. Table 1 shows the demographic characteristics of the respondents by gender, age, education (where they were graduated), current department, years of experience, history of needle stick injury (NSI) and total number of NSIs per year.

\section{KNOWLEDGE, ATTITUDE, AND PRACTICE OF HOUSE OFFICERS ON NEEDLE STICK INJURY}

Table 2 shows the answers by house officers in UKMMC injuries. The results show that majority of them were at an average level of knowledge, while their attitude and practice levels were satisfactory. There were $8.6 \%$ of them who did not answer correctly on what to do immediately after NSI, but majority of them (81.5\%) were aware on which department should they report an NSI to. Among them, $84.8 \%$ knew that the possibility of transmitting HBV is higher than HIV, however, only $2.0 \%$ knew the global transmission rate of those two infections. It also shows that there were $22.5 \%$ who did not know that HCV can be transmitted via NSI. Majority (92.7\%) of the house officers were aware that needles should not be recapped after use and $85.4 \%$ of them follow the correct practice. $23.8 \%$ were under the impression that post-exposure prophylaxis is not necessary. $100 \%$ knew that NSI should be reported however $11.3 \%$ admitted to not reporting the incidence. Majority (99.3\%) aware the need of discarding needles immediately after use and $100 \%$ discarded needles into sharp bin. Majority (90.1\%) also use glove while doing phlebotomy procedure, despite $35.8 \%$ did not think gloves can provide protection against NSI. Most of them (98\%) have been vaccinated against $\mathrm{HBV}$.

The mean knowledge score of the respondents was fairly similar between different demographic groups, the lowest was 6 and the highest was 7 whereas the lowest and highest mean attitude scores were 7.92 and 9.5, respectively, in which they were not significantly associated. Using T-test, the mean practice score was significantly associated with a history of needle NSI $(p<0.05)$, with the lower mean score for those with history of NSI (8.9) compared to without NSI was (9.4) (Table 3.3). ANOVA and post hoc test showed that the mean practice score between HOs with zero total number of NSI per year and HOs and 2 total number of NSI per year was significantly associated. Otherwise other demographic backgrounds were not significantly related. Spearman correlation showed that there was a small positive correlation between knowledgeattitude $(\mathrm{p}<0.05, \mathrm{r}=0.269)$ and attitude-practice $(\mathrm{p}<0.05$, $r=0.175)$ (Table 4).

\section{RELATIONSHIPS BETWEEN PREVALENCE OF NEEDLE STICK INJURY AND GENDER, AGE, EDUCATION, YEARS OF EXPERIENCE AND TOTAL NSI PER YEAR}

Table 6 shows the relationship between the prevalence of NSI and gender, age, education, years of experience and total NSI per year using a chi square test. The results show that there was no significant relationship between history of NSI and the demographic data $(\mathrm{p}>0.05)$. Although most of the 55 respondents who claimed to have history of NSI were below 27 years old $(51 \%)$, gender wise female $(67.3 \%)$, had more than 1 year working experience $(80 \%)$, the differences were not statistically significant. $63.6 \%$ of them had 1 total number of NSI per year whereas others were 2-4.

TABLE 1. Demographic data

\begin{tabular}{|c|c|c|}
\hline Demographic & Frequency (n) & Percentage $\%$ \\
\hline \multicolumn{3}{|l|}{ Gender } \\
\hline Male & 53 & 35.1 \\
\hline Female & 98 & 64.9 \\
\hline Total & 151 & 100.0 \\
\hline \multicolumn{3}{|l|}{ Age } \\
\hline$<27$ & 68 & 45 \\
\hline$>27$ & 83 & 55 \\
\hline Total & 151 & 100.0 \\
\hline \multicolumn{3}{|l|}{ Education } \\
\hline \multirow[t]{3}{*}{ Local Oversea Total } & 82 & 54.3 \\
\hline & 69 & 45.7 \\
\hline & 151 & 100.0 \\
\hline
\end{tabular}




\begin{tabular}{|c|c|c|}
\hline \multicolumn{3}{|l|}{ Current department } \\
\hline Surgery & 24 & 15.9 \\
\hline $\mathrm{O} \& \mathrm{G}$ & 28 & 18.5 \\
\hline Pediatric & 35 & 23.2 \\
\hline Internal Medicine & 30 & 19.9 \\
\hline Orthopedic & 34 & 22.5 \\
\hline Total & 151 & 100.0 \\
\hline \multicolumn{3}{|l|}{ Years of experience } \\
\hline$<1$ year & 41 & 27.2 \\
\hline$>1$ year & 110 & 72.8 \\
\hline Total & 151 & 100.0 \\
\hline \multicolumn{3}{|l|}{ History of NSI } \\
\hline Yes & 55 & 36.4 \\
\hline No & 96 & 63.6 \\
\hline Total & 151 & 100.0 \\
\hline \multicolumn{3}{|l|}{ Total NSI/year } \\
\hline 0 & 96 & 63.6 \\
\hline 1 & 35 & 23.2 \\
\hline 2 & 14 & 9.3 \\
\hline 3 & 4 & 2.6 \\
\hline 4 & 2 & 1.3 \\
\hline$>4$ & 0 & 0.0 \\
\hline Total & 55 & 100.0 \\
\hline
\end{tabular}

TABLE 2. Respondents answers on KAP TOTAL CORRECT/WRONG

\begin{tabular}{|c|c|c|c|}
\hline \multirow[t]{2}{*}{ KNOWLEDGE STATEMENTS } & \multicolumn{2}{|c|}{ ANSWER } & \multirow[t]{2}{*}{ TOTAL } \\
\hline & CORRECT & WRONG & \\
\hline $\begin{array}{l}\text { What should you do after NSI } \\
\mathrm{n} \\
\%\end{array}$ & $\begin{array}{l}138 \\
91.4\end{array}$ & $\begin{array}{l}13 \\
8.6\end{array}$ & $\begin{array}{l}151 \\
100\end{array}$ \\
\hline $\begin{array}{l}\text { Is there more possibility } \\
\text { transmitting HBV than HIV } \\
\text { by NSI } \\
\text { n } \\
\%\end{array}$ & $\begin{array}{l}128 \\
84.8\end{array}$ & $\begin{array}{c}23 \\
15.2\end{array}$ & $\begin{array}{l}151 \\
100\end{array}$ \\
\hline $\begin{array}{l}\text { To which department do you } \\
\text { report NSI }\end{array}$ & & & \\
\hline $\begin{array}{l}\mathrm{n} \\
\%\end{array}$ & $\begin{array}{l}123 \\
81.5\end{array}$ & $\begin{array}{c}28 \\
18.5\end{array}$ & $\begin{array}{l}151 \\
100\end{array}$ \\
\hline $\begin{array}{l}\text { HCV can be transmitted by } \\
\text { NSI } \\
\text { n } \\
\%\end{array}$ & $\begin{array}{l}117 \\
77.5\end{array}$ & $\begin{array}{c}34 \\
22.5\end{array}$ & $\begin{array}{l}151 \\
100\end{array}$ \\
\hline $\begin{array}{l}\text { What is HIV and HBV per- } \\
\text { centage transmission follow- } \\
\text { ing NSI } \\
\mathrm{n} \\
\%\end{array}$ & $\begin{array}{l}3 \\
2\end{array}$ & $\begin{array}{c}148 \\
98\end{array}$ & $\begin{array}{l}151 \\
100\end{array}$ \\
\hline
\end{tabular}




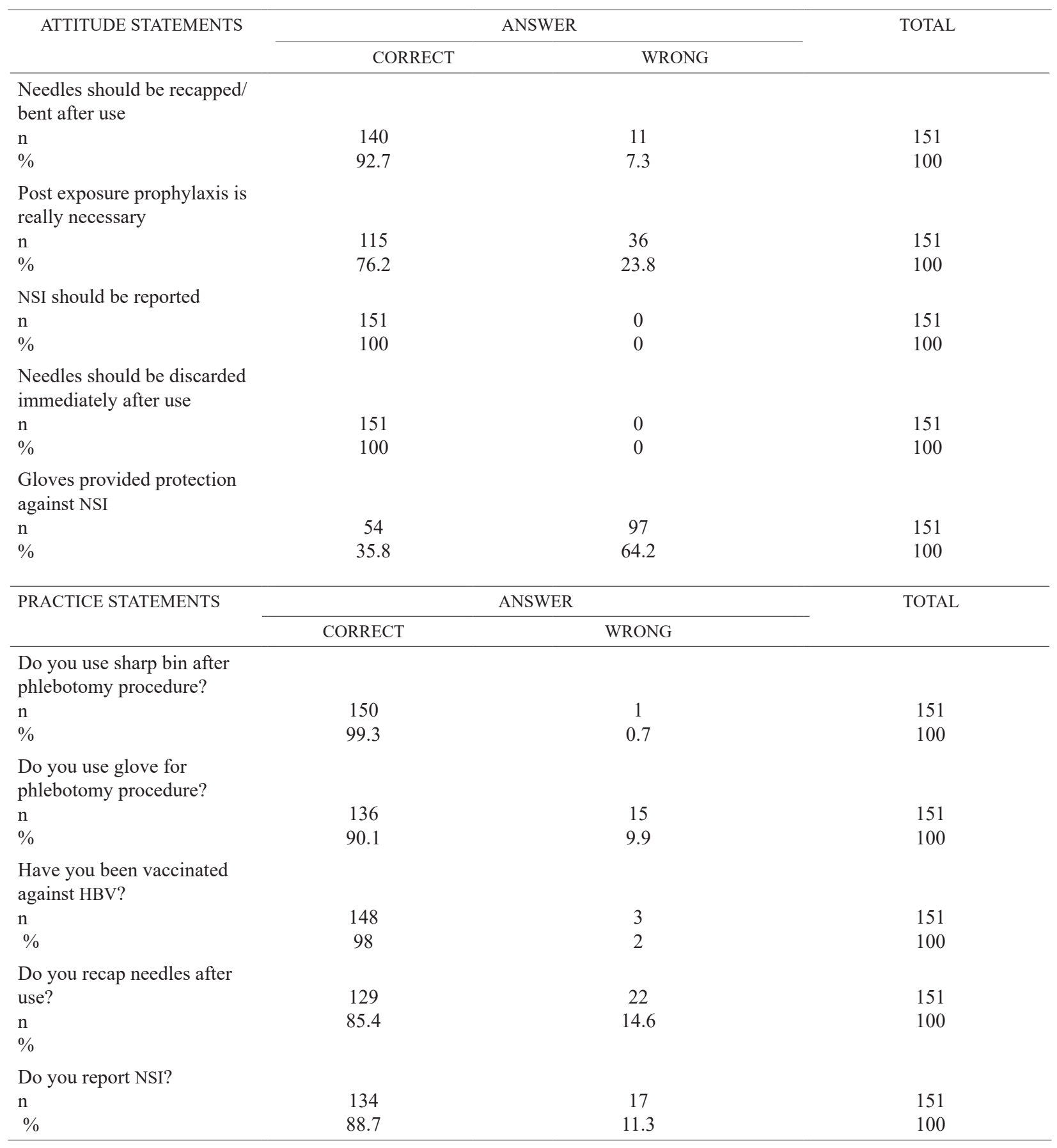

TABLE 3.1 Mean knowledge score versus demographic data

\begin{tabular}{|c|c|c|c|c|c|}
\hline Demographic data & & $\begin{array}{c}\text { Mean knowledge } \\
\text { score }\end{array}$ & Standard deviation & Total number & P-value \\
\hline \multirow[t]{2}{*}{ Age } & $<27$ & 6.8529 & 1.35233 & 68 & 0.276 \\
\hline & $\geq 27$ & 6.5783 & 1.66836 & 83 & \\
\hline \multirow[t]{2}{*}{ Gender } & Male & 6.9057 & 1.54751 & 53 & 0.232 \\
\hline & Female & 6.5918 & 1.52530 & 98 & \\
\hline \multirow[t]{2}{*}{ Education } & Local & 6.8537 & 1.40653 & 82 & 0.187 \\
\hline & Oversea & 6.5217 & 1.66812 & 69 & \\
\hline \multirow[t]{2}{*}{ Year of experience } & $<1$ year & 6.7317 & 1.71791 & 41 & 0.885 \\
\hline & $\geq 1$ year & 6.6909 & 1.46985 & 110 & \\
\hline \multirow[t]{2}{*}{ History of NSI } & Yes & 6.6182 & 1.62721 & 55 & 0.613 \\
\hline & No & 6.7500 & 1.48678 & 96 & \\
\hline
\end{tabular}


TABLE 3.2. Mean attitude score on demographic data

\begin{tabular}{|c|c|c|c|c|c|}
\hline Demographic data & & Mean attitude score & Standard deviation & Total number & P-value \\
\hline \multirow[t]{2}{*}{ Age } & $<27$ & 8.0294 & 1.56425 & 68 & 0.704 \\
\hline & $\geq 27$ & 8.1205 & 1.37395 & 83 & \\
\hline \multirow[t]{2}{*}{ Gender } & Male & 8.1887 & 1.62973 & 53 & 0.500 \\
\hline & Female & 8.0204 & 1.36208 & 98 & \\
\hline \multirow[t]{2}{*}{ Education } & Local & 8.0244 & 1.45700 & 82 & 0.615 \\
\hline & Oversea & 8.1449 & 1.46805 & 69 & \\
\hline \multirow[t]{2}{*}{ Year of experience } & $<1$ year & 8.3415 & 1.54288 & 41 & 0.179 \\
\hline & $\geq 1$ year & 7.9818 & 1.42057 & 110 & \\
\hline \multirow[t]{2}{*}{ History of NSI } & Yes & 7.8545 & 1.43266 & 55 & 0.152 \\
\hline & No & 8.2083 & 1.46479 & 96 & \\
\hline
\end{tabular}

TABLE 3.3. Mean practice score on demographic data

\begin{tabular}{|c|c|c|c|c|c|}
\hline Demographic data & & Mean practice score & Standard deviation & Total number & P-value \\
\hline \multirow[t]{2}{*}{ Age } & $<27$ & 9.0588 & 1.44431 & 68 & 0.141 \\
\hline & $\geq 27$ & 9.3735 & 1.16568 & 83 & \\
\hline \multirow[t]{2}{*}{ Gender } & Male & 9.1698 & 1.26697 & 53 & 0.669 \\
\hline & Female & 9.2653 & 1.32813 & 98 & \\
\hline \multirow[t]{2}{*}{ Education } & Local & 9.2683 & 1.31514 & 82 & 0.719 \\
\hline & Oversea & 9.1884 & 1.29791 & 69 & \\
\hline \multirow[t]{2}{*}{ Year of experience } & $<1$ year & 9.0244 & 1.42281 & 41 & 0.234 \\
\hline & $\geq 1$ year & 9.3091 & 1.25432 & 110 & \\
\hline \multirow[t]{2}{*}{ History of NSI } & Yes & 8.9091 & 1.57847 & 55 & $0.021^{*}$ \\
\hline & No & 9.4167 & 1.08256 & 96 & \\
\hline
\end{tabular}

TABLE 4. Correlation between knowledge-attitude, knowledge-practice and attitude- practice

\begin{tabular}{lll}
\hline Spearman Correlation & $\mathrm{r}$ - value & $\mathrm{P}$ - value \\
\hline Knowledge - Attitude & 0.16 & $<0.038^{*}$ \\
Knowledge - Practice & 0.11 & $>0.879$ \\
Attitude - Practice & 0.175 & $<0.033^{*}$ \\
\hline
\end{tabular}


TABLE 5. KAP Level of house officer with history of NSI and its relationship with demographic data

\begin{tabular}{|c|c|c|c|c|c|c|c|c|c|c|c|c|c|c|}
\hline \multirow[t]{3}{*}{$\begin{array}{l}\text { Demographic } \\
\text { factors }\end{array}$} & \multicolumn{10}{|c|}{$\begin{array}{c}\text { Knowledge }(\mathrm{K}), \text { Attitude(A), Practice }(\mathrm{P}) \\
\text { total score }\end{array}$} & \multirow[t]{3}{*}{$\begin{array}{c}\text { Total } \\
\mathrm{K}\end{array}$} & \multirow{2}{*}{\multicolumn{3}{|c|}{$\mathrm{P}$-value }} \\
\hline & \multicolumn{3}{|c|}{ Poor (0-4) } & \multicolumn{3}{|c|}{ Average (5-6) } & \multicolumn{4}{|c|}{ Satisfactory $(>7)$} & & & & \\
\hline & $\mathrm{K}$ & $\mathrm{A}$ & $\mathrm{P}$ & $\mathrm{K}$ & $\mathrm{A}$ & $\mathrm{P}$ & $\mathrm{K}$ & $\mathrm{A}$ & $\mathrm{P}$ & & & $\mathrm{A}$ & $\mathrm{P}$ & \\
\hline \multirow{3}{*}{ Gender } & Male & 3 & 1 & 1 & 4 & 6 & 0 & 11 & 11 & 17 & 18 & & & \\
\hline & Female & 5 & 0 & 1 & 15 & 7 & 4 & 17 & 30 & 32 & 37 & & & \\
\hline & Total & 8 & 1 & 2 & 19 & 13 & 4 & 28 & 41 & 49 & 55 & 0.424 & 0.164 & 0.164 \\
\hline \multirow[t]{3}{*}{ Age } & $<27$ & 7 & 1 & 2 & 17 & 12 & 4 & 26 & 37 & 44 & 50 & & & \\
\hline & $\geq 27$ & 1 & 0 & 0 & 2 & 1 & 0 & 2 & 4 & 5 & 5 & & & \\
\hline & Total & 8 & 1 & 2 & 19 & 13 & 4 & 28 & 41 & 49 & 55 & 0.839 & 1.0 & 0.714 \\
\hline \multirow[t]{3}{*}{ Education } & Local & 3 & 1 & 1 & 14 & 7 & 4 & 15 & 24 & 27 & 32 & & & \\
\hline & Oversea & 5 & 0 & 1 & 5 & 6 & 0 & 13 & 17 & 22 & 23 & & & \\
\hline & Total & 8 & 1 & 2 & 19 & 13 & 4 & 28 & 41 & 49 & 55 & 0.191 & 1.0 & 0.156 \\
\hline Years of & $<1$ year & 4 & 0 & 1 & 3 & 0 & 0 & 4 & 11 & 10 & 11 & & & \\
\hline \multirow[t]{2}{*}{ Experience } & $\geq 1$ year & 4 & 1 & 1 & 16 & 13 & 4 & 24 & 30 & 39 & 44 & & & \\
\hline & Total & 8 & 1 & 2 & 19 & 13 & 4 & 28 & 41 & 49 & 55 & 0.112 & 0.058 & 0.482 \\
\hline \multirow[t]{6}{*}{ Total No/Year } & 1 & 5 & 1 & 2 & 14 & 11 & 0 & 16 & 23 & 33 & 35 & & & \\
\hline & 2 & 2 & 0 & 0 & 3 & 2 & 4 & 9 & 12 & 10 & 14 & & & \\
\hline & 3 & 0 & 0 & 0 & 2 & 0 & 0 & 2 & 4 & 4 & 4 & & & \\
\hline & 4 & 1 & 0 & 0 & 0 & 0 & 0 & 1 & 2 & 2 & 3 & & & \\
\hline & $>4$ & 0 & 0 & 0 & 0 & 0 & 0 & 0 & 0 & 0 & 0 & & & \\
\hline & Total & 8 & 1 & 2 & 19 & 13 & 4 & 28 & 41 & 49 & 55 & 0.549 & 0.606 & $0.035^{*}$ \\
\hline
\end{tabular}

TABLE 6. Demographic data of HO with history of NSI

\begin{tabular}{lccc}
\hline Demographic & Frequency & Percent & p-value \\
\hline Gender & & & \\
Male & 18 & 32.7 & \\
Female & 37 & 67.3 & 0.644 \\
Total & 55 & 100.0 & \\
Age & & & \\
$<27$ & 28 & 51 & \\
$\geq 27$ & 27 & 49 & 0.356 \\
Total & 55 & 100.0 & \\
Education & & & \\
Local & 32 & 58.2 & \\
Oversea & 23 & 41.8 & 0.469 \\
Total & 55 & 100.0 & \\
Years of experience & & & \\
$<1$ year & 11 & 20.0 & \\
$>1$ year & 44 & 80.0 & 0.135 \\
Total & 55 & 100.0 & \\
\hline
\end{tabular}




\section{DISCUSSION}

This study was done in view of the limited number of similar studies assessing the Knowledge, Attitude and Practice of HOs in hospitals in Malaysia on needle stick injuries which are one of the hidden problems among healthcare personnel. These findings show that the prevalence of NSI among house officers in UKMMC was approximately one third of total population (36.4\%).

This is considered high compared to the prevalence of NSI among HCWs in Melaka General Hospital that was 20.9\% (Bhardwaj et al. 2014) and in Hospital Serdang in 2010 that was $23.5 \%$ (Rampal et al. 2010). The high prevalence in UKMMC can possibly be explained by the heavy workload within a limited time plus the inadequate experience of HOs themselves. However, the variations in NSIs prevalence can also be explained by different number of HCWs per hospital, various work cultures and environments, differences in the availability of resources, measurement methods and research designs (Motaarefi et al. 2016).

Among $36.4 \%$ of those HOs with history of NSI, they were equally distributed among their age group, education background, genders and years of experience. There was no significant relation between the demographic data of HO and history of NSI. Similarly, no gender variation was observed in a study by Muhammad Shahzad et al. (2013) among house officers.

The mean knowledge score for NSI among the HOs was 6.702 and is classified as average. The mean attitude score was 8.649 and classified as satisfactory while the mean practice score was 9.232 , which was satisfactory. The reason to why the HOs have average knowledge total score may be due to acquisition of knowledge are from informal lectures and clinical activities and during their formative learning years, they developed improper working habits as reported by Norsayani and Noor Hassim (2003).

This study showed that there were no significant differences among the HOs with various demographic factors (gender, age, department, education background, year of experience, and history of NSI) and the mean knowledge and attitude total score. This could be due to having to work under the same system that narrowed the gap caused by the demographic background variation.

However, there is a significant difference in the mean practice score of the HOs with history of NSI, indicating that HOs with no history of NSI had a higher mean score compared to those with history of NSI. This study showed that house officers who had a needle stick injury case has a lower score in practice of universal precaution compared to non-cases. Therefore, exposure prevention among the house officers or students must be an institutional concern and a strengthening effort of universal work precautions during clinical skills at an early phase of the medical curriculum is mandatory (Kavitha et al. 2015). Completion of three doses of Hepatitis B must be reiterated and they must also be aware of their antibody status (Gershon et al. 2005).

With regards to practices, in a study, about $37 \%$ of doctors, 19\% nurse, 31\% technicians and 58\% attendants believed that there is no harm in recapping or bending the needles after use even though recapping needles is prohibitive by OSHA blood-borne pathogen standard. Prompt management of exposure including the use of post-exposure prophylaxis is important to prevent the establishment of infection after an accidental exposure of a HCW to an infectious source material has occurred. However, one study reviewed that only 10\% (30 out of 282) of healthcare worker knew about post-exposure prophylaxis (Eticha \& Gemeda 2019).

This study showed that there was a positive correlation between knowledge and attitude of the respondents, and between attitude and practice of HOs regarding NSI. There was no positive correlation between knowledge and practice observed from this study, contradicting a study conducted by Hamid et al. (2010) in a tertiary hospital; whereby there was a small positive correlation between knowledge and actual practice of the universal precaution. This may be because of the limitations that the HOs encountered throughout their houseman ship period in UKMMC; such as time constraint which had cause them to neglect the proper practice regarding needles handling hence leading to NSI as reported in a study done in Melaka (Swe et al. 2012). Awareness about universal precaution guidelines, only $21.6 \%$ (65 out 282 ) of HCW were found to be aware (Khurram et al. 2008).

These results are to be used for future interventions not only within the study venue but also in other hospitals. The limitation of this study may have caused an undesired bias as the respondents may have given a socially desirable answer. In addition to that, this study population may have not represented other healthcare workers within UKMMC, thus, this may have affected the prevalence of NSI as a whole. This study was unable to establish the causalities; thus, we suggest that in the future, this study should be continued to include pre- and post-intervention of the Knowledge, Attitude and Practice assessment; in order to achieve an optimum efficiency.

In conclusion, the results showed that the HOs of UKMMC have an average level of knowledge regarding NSI as only a minority of them are aware of the global transmission rate of $\mathrm{HBV}$ and $\mathrm{HCV}$. Otherwise, the HOs had satisfactory attitude and practice in handling needles as majority of them followed the standard operational 
procedure of not recapping needles after use and they were aware of discarding needles immediately after use into the sharp bin. All of them knew that NSIs should be reported.

\section{ACKNOWLEDGEMENTS}

We would like to express our gratitude to the Faculty of Medicine, Universiti Kebangsaan Malaysia for the permission to collect data and approval of this study with the approval code of FF-2018-180.

\section{REFERENCES}

Bhardwaj, A., Sivapathasundaram, N., Yusof, M., Minghat, A., Swe, K. \& Sinha, N. 2014. The prevalence of accidental needle stick injury and their reporting among healthcare workers in orthopaedic wards in General Hospital Melaka, Malaysia. Malaysian Orthopaedic Journal 8(2): 6-13.

Bhargava, A., Mishra, B., Thakur, A., Dogra, V., Loomba, P. \& Gupta, S. 2013. Assessment of knowledge, attitude and practices among healthcare workers in a tertiary care hospital on needle stick injury. Int. J. Health Care Qual. Assur. 26(6): 549-558.

Bilks, B. 2005. Needle stick injuries in nurses - the Poznan study. Into. J. Occupy. Med. Environ. Heath. 18: 251-254.

Calver, J. 1997. Occupational health services. Am. J. Infect. Control. 25: 363-265.

Centre for Disease Control and Prevention (CDC). 2008. https://www.cddc.gov/niosh/topics/bbp/emergnedl.html. Accessed on Sept 12, 2019.

Eticha, E.M. \& Gemeda, A.B. 2019. Knowledge, attitude, and practice of postexposure prophylaxis against hiv infection among healthcare workers in Hiwot Fana Specialized University Hospital, Eastern Ethiopia. AIDS Research and Treatment. 2019: Article ID. 7947086. doi:10.1155/2019/7947086

Gershon, R.R., Mitchell, C., Sherman, M.F., Vlahov, D., Lears, M.K., Felknor, S. \& Lubelczyk, R.A. 2005. Hepatitis B vaccination in correctional health care workers. Am. J. Infect Control 33(9): 510-518.

Hamid, M.Z.A., Aziz, N.A., Anita, A.R. \& Norlijah, O. 2010. Knowledge of blood-borne infectious diseases and the practice of universal precautions amongst health-care workers in a tertiary hospital in Malaysia. Southeast Asian J. Trop. Med. Public Health 41(5): 1192-1199.

Kavitha Nagandla, Krishna Kumar, Amit Bhardwaj, Devalagan Muthalagan, Chan, Yhmin, Lee Wei Lun, Weng Wei Shi \& Nurul Izzati Abd Razak. 2015. Prevalence of needle stick injuries and their underreporting among healthcare workers in the department of obstetrics and gynaecology. International Archives of Medicine 8: 2015.

Khurram, S., Shirin. M., Syeda, F.T., Idress, A. \& Asif Zafar, M. 2008. Knowledge attitude and practices regarding needle stick injuries amongst healthcare providers. Pakistan Journal of Surgery 24(4): 243-248.

Kirchner, B. 2012. Safety in ambulatory surgery centers: Occupational safety and health administration surveys. AORN Journal 96: 540.
Muhammad Shahzad, Syed Ghazanfar Hassan, Muhammad Rizwan Memon, Uzma Bashir \& Salman Shams. 2013. Needle sticks injuries among dental students, house officers and paradental staff working at Liaquat Medical University Hospital, Hyderabad. Pakistan Oral \& Dental Journal 33(1): 23-25.

Motaarefi, H., Mahmoudi, H., Mohammadi, E. \& HasanpourDehkordi, A. 2016. Factors associated with needlestick injuries in health care occupations: A systematic review. Journal of Clinical and Diagnostic Research 10(8): IE01-IE04.

Nagandla, K., Kumar, K., Bhardwaj, A., Muthalagan, D., Lun, L.W., Shi, W.W. \& Abd Razak, N.I. 2015. Prevalence of needle sticks injuries and their underreporting among healthcare workers in the department of obstetrics and gynaecology. International Archives of Medicine 8(181): $1-16$.

Norsayani, M.Y. \& Noor Hassim, I. 2003. Study on incidence of needle stick injury and factors associated with this problem among medical students. J. Occup. Health. 45(3): 172-178.

Rampal, L., Zakaria, R., Whye Sook, L. \& Azhar, M.Z. 2010. Needle stick and sharps injuries and factors associated among health care workers in a Malaysian hospital. European Journal of Social Sciences 13(3): 354-362.

Rogers, B. \& Goodno, L. 2000. Evaluation of interventions to prevent needle stick injuries in health care occupations. Am. J. Prev. Med. 18: 90-98.

Saleem, T., Khalid, U., Ishaque, S. \& Zafar, A. 2010. Knowledge, attitudes and practices of medical students regarding needle stick injuries. Journal of Pakistan Medical Association 60(2): 151-156.

Sharew, N.T., Mulu, G.B., Habtewold, T.D. \& Gizachew, K.D. 2017. Occupational exposure to sharps injury among healthcare providers in Ethiopia regional hospitals. Annals of Occupational and Environmental Medicine 29(7). doi:10.1186/s40557-017-0163-2.

Swe, M.M.M., Zin, T., Bhardwaj, A., Lutfi Abas, A. \& Barua, A. 2012. The prevalence of needle sticks injury among medical students in Melaka, Malaysia. European Journal of Scientific Research 71(2): 214-220.

Vaz, K., McGrowder, D., Alexander-Lindo, R., Gordon, L., Brown, P. \& Irving, R. 2010. Knowledge, awareness and compliance with universal precautions among health care workers at the University Hospital of the West Indies, Jamaica. Int. J. Occup. Environ. Med. 1(4): 171-181.

Woolley, P.D., Palfreeman, A.J., Patel, R., Talbot, M.D. \& Samarasinghe, P.L. 1991. Blood-taking practices and needle-stick injuries in house officers. Int. J. STD AIDS. 2(1): 46-48.

World Health Organization (WHO). Occupational HealthNeedlestick Injuries 2002. https://www.whi.int/occupational health/topics/needinjuries/en/. Accessed on Sept 12, 2019.

Zhang, M., Wang, H., Miao, J., Du, X., Li, T. \& Wu, Z. 2009. Occupational exposure to blood and body fluids among health care workers in a general hospital, China. Am. J. Ind. Med. 52(2): 89-98. 
Ahmad Syahmi Mohd Azman, Khairulini Mohd Amirol, Lee Pei Chieh, Nurshafiqah Rosli, Nur Anis Nadirah Zulkifli \& Nur Azlina Mohd Fahami*

Department of Pharmacology

Universiti Kebangsaan Malaysia Medical Centre

56000 Cheras, Kuala Lumpur, Federal Territory

Malaysia

Khamsiah Nawawi

Occupational, Safety, Health and Environment Division

Universiti Kebangsaan Malaysia Medical Centre

56000 Cheras, Kuala Lumpur, Federal Territory

Malaysia
*Corresponding author; email: nurazlinamf@ukm.edu.my

Received: 13 December 2019

Accepted: 2 June 2020 